\title{
Moral Aspect in the Law Enforcement in Indonesia: Prophetic Perspective
}

\author{
Siti Zuliyah and Triwahyuningsih Triwahyuningsih \\ Civics and Pancasila Education Study Program \\ Universitas Ahmad Dahlan \\ Yogyakarta, Indonesia \\ sitizuliyah@gmail.com
}

\begin{abstract}
Law enforcement in Indonesia is still moving around the positivism paradigm, the view that law does not derive from God or the universe. Instead, law comes from human, separating it from morality. Automatically, it leads to isolate law from moral and religious values, making it a mere instrument, a la Bouche de la loi (mouthpiece of law), hammer tapper of the legal text formulated in a space of power which leads it far away from the sense of justice. The aim of the study is to know (1) why moral dimension is necessary in the law enforcement in Indonesia; and (2) the concept of law enforcement in Indonesia to realize true justice. The research employed juridical sociological approach to analyze the legislative regulations as well as the underlying values of the law enforcement system in Indonesia. Sociological approach was used to analyze the cases, starting from the investigation process, prosecution, to trial. The research results show that law enforcement in Indonesia requires moral dimension to actualize true justice by seeing human's dignity as the core values. A law enforcer should value the principles of humanity, such as righteousness, honesty, kindness, justice, freedom, and happiness. Law enforcement in Indonesia applies prophetic concept that combines social and religious values for the benefits of the people.
\end{abstract}

Keywords-moral dimension; law enforcement; prophetic

\section{INTRODUCTION}

Positivism focuses on the formality based on real project and is deducted from the significant logics in the study of law. Law is viewed as autonomous and pure institutions. Thus, to make it legitimate and applicable, laws cannot and must not be interfered by illegal aspects, such as politics, social economics, and morality. The legal theory of liberalism highly protects an individual's freedom. Therefore, it is significant to implement Positivism regulation [1].

Positivism school views that law does not derive from God or universe. Instead, it comes from human based on the provision to separate law and moral. Positivism comes from the ideas that law is regulatory and general. It is stipulated by the state authorities. There is a separation between norms/policies and ethics/morals, and between justice and legality [2].

Legislative regulations are the products of ideas completely containing law. This way, judge can implement the legislative provisions systematically and linearly to solve the problems in the society. Law is no longer thought as abstract meta-juridical principles of the nature of justice. Instead, it has been positivized as lege or lex to guarantee legal certainty [2].

Law enforcers in Indonesia, which only serve as the instruments of law, the mouthpiece of law, and the gavel tappers of the legal text formulated in the space of authority, measure social justice by rigid and dogmatic articles. Law has been marginalized in the society. It is indeed abolished. The worst, among the sacralism oflogical articles, law enforcers are used to buy and sell the articles of law.

Satjipto Rahardjo criticizes the problems of law enforcement in Indonesia. First, it only works in the supremacy of laws and rhetoric supremacy of the state of law. In fact, the spirit of justice, honesty, and authenticity of law enforcement weakened and disappeared. Indonesia is a state of law, but the law has undergone severe derogation. In this case Satjipto criticized money politics in the process of settling the case. Second, law enforcement works on the slow lane with long, complicated, and costly process. Third, law enforcement in Indonesia has lost its moral legitimation because the people have traded it. Fourth, law enforcement is no longer equal to the orderliness. It is one of the orientations of law enforcement, but it lacks of social aspects because people violate the law. Fifth, law enforcement is dominant and without sociological strategies. Thus, it is fully loaded with corruption, collusion, and nepotism [3]

In general, Satjipto's critics are mostly about the disorientation of law enforcement in Indonesia. According to him, law is for human. Meanwhile, the real practice works the otherwise. Law should be for broader aspects of human's dignity, those are happiness, prosperity, and respectability [4]. Besides, Satjip to worries about the formalism and marginalization of law enforcement to the living law. For him, law is not the only absolute and final institution because it is always an ongoing process [5]. Thus, the settlement in the formal way should not be enforced if it is unnecessary or if it burden the people.

A research by Khudzaifah Dimyati et. al, on the judges' profiles in enforcing the nobility, dignity, and honor of a professions, shows that:

First, seen from the ontological aspects, the judges state that the concepts of law being used serve as the legislative regulations. However, 13 judges added that in particular 
conditions, the concept also bases on the conventional values of the society.

Second, seen from the epistemological aspect, all judges stated that the logical thinking to use is deductive. Yet, 9 judges added that inductive method also works and 1 judge stated that inductive is the only method.

Third, from the axiological aspect, 6 judges stated that good verdict is in accordance with the applicable regulations; 4 judges stated that that it should reflect the applicable values of the society (justice); and 8 judges stated that good verdict should be in line with applicable regulations as well as values of the society [6].

Fundamental position of the law enforcers requires them to be able to take proper, ethical, and fair decision. They should not only rely on the articles of laws, but also on the social and humanities aspects of particular cases. The more they look only on regulatory factors, the more they see it as closed legalistic formal unit. Conversely, the more they look on humanities, the more it is opened in terms of social and humanity mosaic [7].

Based on the description, we can see that there is a problematic crisis in the morality awareness of the law enforcers in Indonesia. The condition leads to create stagnant, centralistic, corruptive, and less humanitarian enforcers.

\section{FORMULATION OF THE PROBLEM}

From the above explanation, the research focuses on (1) why moral aspects are necessary in the law enforcement in Indonesia and (2) what is the prophetic perspective in creating true justice?

\section{RESEARCH METHOD}

The research employed sociological juridical approaches. Juridical approach is used to analyze the legislative regulations as well as the underlying values in the system of law enforcement in Indonesia. Meanwhile, sociological approach is used to analyze the cases in the system.

\section{DISCUSSION}

\section{A. Moral Aspects in the Law Enforcement}

\section{1) Definition of Ethics and Moral}

There is a difference between ethics and moral. Ethics comes from old Greek "ethos". It is a singular noun with several meaning; those are common dwelling, meadow, habit, custom, ethics, character, emotion, attitude, and way of thinking. Based on the origin, ethics is a science of customs or daily habits. However, the definition is not sufficient to explain completely the meaning of ethics [8].

Ethics is also philosophical thinking on what is good and bad of human's behavior that contains responsibility. It is called philosophical thinking because, historically, ethics developed along with the development of philosophy. In Greek philosophy, ethics is originated from the speculation of good living systematized in philosophy and is thereby called ethics. The word refers to custom, the ideas of good and bad of human [9].
In further development, ethics is considered to be part of philosophy, or what is called philosophy of moral teachings. However, the meaning is sometimes overlapped with morals. It occurs as the result of lack of understanding of the use of the term [9].

Moral problem refers to the good and bad of human as human, instead of relating them to other human aspects. Moral aspects are the scope of human life seen from their kindness as human. Moral is the benchmark to determine the right and wrong of human attitudes and acts. It does not relate those aspects to particular and limited role of human [10]. The problem that arises is how to assure that particular moral norm is correct, thus making it applicable. On this, Immanuel Kant suggested a way out through a process of generalizing moral norm, which is known as the golden rule: "treat others how you want to be treated." If we are confused of what to do in particular situation, we should hold on to this golden rule [11].

\section{2) Moral and Laws}

Laws and moral are distinguishable yet inseparable. Both influence and strengthen each other. In relation to other social norms (religious and politeness norms), the specific function of legal norms is regulating the human interests based on other social norms, particularly by giving sanction. Besides, it is also to protect their interest.

Hart states that there is a separation between laws and morality. Even so, it is not extreme because morality is part of legal requirements. The condition arises of two factors: first, human is limited in doing good deeds to others, and second, laws has its limitation in organizing the development of the society.

Hart suggested that morality be the minimum legal requirements, by limiting the inflexibility of Austen's classic positivism. In Austen's ideas, law is seen as moral-proof institution. However, to certain extent, Hart and Austin agree to the idea of separating laws and morality and disagree to the absolute isolation of morality [9].

According to Hart, the relation between laws and morality can be seen in the following. First, laws manifest the ideas of morality. Second, morality and laws are separate. Third, law should actualize the ideas of law. Fourth, morality values influence laws. Fifth, law, by definition, covers moral. And sixth, law sees the natures of human being and the world they live in, as well as the principles of morality of at least similar aspects [12].

Hart proposes that legal system is social regulation system. For example, regulation usually becomes the justification of particular acts and violation is open to criticism. Therefore, law regulation is normative, while custom is the otherwise. In other words, regulation confirms the rights and authorities, while custom does not have any power to regulate an individual's behavior. Validity of dominant positive law is against the custom of subordinate areas [13].

In law, there is specific legal morality, consisting of the reflection of moral opinion exist in the society in general. It is also developed in the legal practice and is tied to the institution and the teachings of laws. Law morality is the specific field of lawyers and law scholars. Frequently, the morality should be 
protected against the majority and political and social interests, such as reasonable principles of legal process in the trials of political intervention.

\section{3) Moral Aspect in Law Enforcement}

Referring to the definition of ethics and moral, ethics in law enforcement is supposed to be the guidance or facility used by law enforcers (Police, prosecutors, judges, and legal counsel) [10]. It is in relation to how they accomplish their duty as law enforcers. The purpose is to preserve their responsibility, to prevent them from possible disorientation, in overcoming several things (moral values and norms) during the trial process. This way, they provide substantial justice to the society.

Law enforcement is fully loaded by human struggles. Other than putting their basis on legal norms, law enforcers also hold on moral values and norms to actualize the judicial authority as an institution of justice, to ensure the manifestation of truthfulness in humanity values. In overcoming various problems, a law enforcer may lose their orientation. Thus, ethics comes to vocalize the right thing to do by law enforcer to the suspect/defendant in relation to the senses of humanity, such as righteousness, honesty, kindness, justice, freedom, happiness, and so on. In the judicial system, the protection of human prestige and dignity is one of the reviews by law enforcers in determining their attitudes. Therefore, persecution of a suspect/defendant cannot be accepted as an appropriate investigation method, for it is not in line with human dignity. It is not only for the goodness of the suspect/defendant, but also for the humanity of the law enforcer.

Immanuel Kant places human dignity as the most basic norm. According to him, we have to respect human dignity because human is the only creature attained by their own willingness. For Kant, everyone has the obligation to respect human dignity. He formulated the ideas into "treat human as it is purposed to treat himself and do not see it as a mere tool." Human dignity should be respected. Human should not be treated like tools, nor should they be manipulated for the purpose other than the purpose of the related being. Kant states that human dignity is the source of obligation of our and other people [11].

Investigation by way of persecution to obtain evidence or confession can never be justified, because the defendant's dignity cannot be violated for the sake of investigation. As moral thinking, ethics require a law enforcer to obey the legal norms. Ethics also review the good and bad of the enforcer in treating the suspect. Good and bad are not limited to particular aspects that indirectly determine the ethical quality of a law enforcer. Instead, the behavior sees him as human being [11].

Law enforcer is a duty based on expertise (as investigator, persecutor, judge, or counselor) that may bring good or bad things to the suspect and/or defendant, as well as to the society. Therefore, he is responsible for the bad decision he takes. Moral responsibility as an enforcer is to follow the law enforcement steps according to the norms in revealing and upholding the righteousness and justice. The responsibility appears in the doctrine of each law apparatus, usually called professional code ethics.
In actualizing the law enforcement, it requires judicial power. The main duties of the judiciary are examining, hearing, determining, and settling the cases claimed by the people. The seeker of justice expect that professional and integrated judges can settle the cases. Thus, it does not only contain legal certainty (procedural judiciary), but also contain legal justice and social justice as the main purposes of dispute settlement [14].

Law enforcer do not only work on formal procedures in the applicable laws in the society. It was stated by Moh Mahfud, MD. He states that upholding the justice is more important than following the procedures of the laws, which are often relate to the law enforcers [14]. In the practice of law enforcement, the law enforcer has performed their duties in their best way. It means that they follow the formal regulation. However, against corruption case, the people are not satisfied by the judge's decision. It becomes the problem of the social justice.

In the laws, the judicial power requires the judges to explore the laws and the sense of justice exist in the society (Article 28 paragraph 1 Laws number 4 Year 2004 on Judicial Power). Therefore, to make a betterment, law enforcers are required to maintain high morality and justice. It is in line with the aims of traditional law of Indonesian people, namely the Justice King. It is similar to the dream of the great Greek philosopher, Plato, with his concept "the philosophical King."

The main duty of a judge is to accept, examine, hear, determine, and settle every case proposed to him. Besides, he also has the duty to examine and hear a case through three sequential stages. First is constatir, meaning to stipulate and formulate the concrete events. Second is qualifying, means to stipulate or formulate the legal incidents and provide the judiciary normatively [14].

Brugt and Winkouman states seven steps to follow by the judge in settling a case [15]. Those are (a) mapping the case; (b) interpreting the case in juridical terms; (c) selecting relevant regulations; (d) analyzing and interpreting the regulations; (e) applying the regulation to the case; (f) evaluating and considering the arguments and the settlement; and (g) formulating the settlement.

From the opinion, it is known that, in reality, there are many non-legal factors in the process of attaining judicial verdict. A judge cannot only follow the procedures and then apply the articles of laws which are suitable with the case. Instead, sociologically, many social variables are related. He should attempt to minimize the range and discrepancy of laws and justice by exploring, following, and understanding the values of law in the society [8].

\section{B. Prophetic Perspective in Law Enforcement}

The terms prophetic comes from English prophetic, which means: (1) of or pertaining to a prophetic inspiration); (2) of the nature of or containing prophecy: prophetic writing; (3) having the function or power of a prophet, as a person; and (4) predictive; ominous; prophetic sign; prophetic warnings [16].

Prophetic is religious approach in relation to science and religion. It includes the views of human relation with the nature. Other than prophetic, various patterns of thinking 
appear in Islam. They attempt to build harmony-integrative relation between science and religion. Social and economic philosopher introduced the term prophetic from the US, Kennth Boulding. He distinguished "church religion" and "prophetic religion". K Untowijoyo, a Moslem historian, uses the term in finding a new pattern to relate science and religion. It is known that the relation between science and religion has been in long dispute. Western history cannot be separated from the conflict of reason and belief, theology and revelation [2].

The ideas of prophetic of social science from Kunto, was inspired by Roger Garaudy. He mentioned that western philosophy cannot be the solution of modern human being because of many dissatisfying factors. It is confused by pointless dispute of two poles, idealist and materialist. Western philosophy (critical philosophy), was originated from the question "how is science possible?". Roger Garaudy return the question with "how is revelation possible? "Dawan Raharjo states that the emergence of "prophetic social science" form Kuntowijoyo is the influence of his interaction with Moeslim Abdurrahman about "theology of liberation", which is the core of "transformative theology." Kunto changed the term transformation into prophetic social science to fill in the gap of decodification and transformation schools [2].

The main ideas of prophetic on the relation of religion and science (especially humanity science), is conducted by integrating and objectifying the normative teachings of the Quran in the objective categories. Islam has to be a paradigm, a theory, which applies objectively, to make it bless. Objectification begins with internalization, to externalization using synthetic analytic method, as well as transcendental structure approach [2]

Law enforcement can be actualized if the justice can be achieved by the law enforcers. The definition of justice has been proposed. Among them is placing an object proportionally. Justice is the balance of rights and obligations, and so on. Similarly, Aristoteles classified justice into commutative and distributive. Justice can also be divided into legal justice, moral justice, and social justice [14].

Islam obliges us to act in justice in settling a case. For example, in Quran Surah An-Nisa 58: "Indeed, Allah commands you to render trust to whom they are due and when you judge between people to judge with justice. Excellent is that which Allah instructs you. Indeed, Allah is ever Hearing and Seeing. "It is further confirmed in the same Surah, verse 135:" O, you who have believed, be persistently standing firm in justice, witnesses for Allah, even if it be against yourselves or parents and relatives. Whether one is rich or poor, Allah is worthier of both. So, follow not personal inclination, lest you not be just. And if you distort your testimony or refuse to give it, then indeed Allah is ever, with what you do, Acquainted."

According to Al-syathiby, the discussion of the purpose of law, oriented on the benefit of the people should be prioritized or given large portion. Law enforcer and Islam contains collections of guidance of life (orders and prohibition) orders the regulation in a society. In relation to the aspects of law, the justice of Islamic law is derived from God the Almighty Fair. Allah is quillmanbilqish. Therefore, human should take responsibility of each of his deed on the day of justice, as stated in Quran Surah An-Nisa, verse110: "And whoever does a wrong or wrongs himself but then seeks forgiveness of Allah will find Allah Forgiving and Merciful."

The practice is fully loaded with Divine values and meanings. Transcendental justice has ideal spirit because the parameter to construct is based on the justice, as ordered and taught by God in the Holy Book. Quran is the main guidelines to explore and formulate the values of justice in a verdict. This justice is the sample given by the prophet and Rasul. The concept is the aim of the prophetic justice, which is in line and synergize with other justice values [14].

Prophetic justice is manifested in the judicial verdict. The base lies at the head of the verdict "Justice on One and Only God". This should be the guideline of the verdict. Thus, the prophetic dimension is applicable without ignoring the available positive law. Procedural and substantive justice can be in line with prophetic justice. Therefore, legal enforcement can be manifested in the sense of true justice.

\section{CONCLUSION}

Sociologically, law enforcement is closely related to various social variables, for it is close with human struggles. Therefore, law enforcers should not only base their work on legal norms, but also on moral norms and values to maintain the judicial authority and to ensure the righteousness in the values of humanity.

Law enforcement in Indonesia requires moral aspect because the main purpose is to achieve true justice by placing human dignity in the basic norm. A law enforcer should hold on the principles of humanity, such as righteousness, honesty, kindness, justice, freedom, and happiness.

Prophetic dimension in law enforcement is based on the religious values of the Quran. It is meaningful and in line with Ilahiyah values. It can be applied by the law enforcers in the judicial system, along with the substantial and procedural justices to achieve true justice.

\section{REFERENCES}

[1] Raharjo. Agus, "Hukum dan Dilema Pencitraan: Transisi Pradigmatis Ilmu Hukum dalam Teori dan Praktik," Jurnal Hukum Pro Justicia, vol. 24 (1), January 2006.

[2] Absori. Acmadi, "Transplantasi Niilai Moral Dalam Budaya Untuk Menuju Hukum Berkeadilan (Prespektif Hukum Sistematik ke Non Sistematik Charles Sampford)," Prosiding Konferensi Nasional ke 6 Asosiasi Perogram Pasca Sarjana Perguruan Tinggi Muhammadiyah (APPPTM), Yogyakarta 2017

[3] Sutjipto. Rahardjo, Sisi lain dari hukum di Indonesia. Jakarta: Buku Kompas, 2003.

[4] Sutjipto. Rahardjo, Membedah hukum progresif. Jakarta: Kompas, 2006.

[5] Sutjipto. Rahadjo. Indonesia inginkan penegak hukum progresif. Kompas, 2002.

[6] K. Dimyati, Absori, K. Wardiono, "Pemetaan Dan Jasa hakim: Profil Hakim Dalam Penegakan keluhuran, Martabat dan Kehormatan Profesi," Proseding Konferesnsi Nasional Ke 2 Asosiasi Program Pasca Sarjana Perguruan Tinggi Muhammadiyah (APPPTM), Yogyakarta 2015.

[7] Bernard. L, Tanya et. al, Teori Hukum Strategi Tertib Manusia lintas Ruang dan Generasi. Yogyakarta: Genta Publising, 2010.

[8] Bertens. K, Etika. Jakarta: Gramedia, 2008 
[9] Khudzaifah. Dimyati, Absori, K. Wordiono, F. Hamdani, Hukum dan Moral Basic Epistimologi Paradigma Rasional. Yogyakarta: Genta Publising, 2017.

[10] Suseno. Frans Magnis, Etika Dasar (Masalah-masalah Pokok Filsafat Moral). Yogyakarta: Kanisius, 1897.

[11] Imanuel. K and Bertens. K, Etika Biomedis. Yogyakarta: Kanisius, 2011.

[12] Luthan. Salman, "Dialektika Hukum dan Moral dalam prespektif filsafat hukum," Jurnal Hukum IUS QUIA IUSTUM. Yogyakarta: Faculty of Law of Universitas Islam Indonesia, vol. 19 (4), October 2012.
[13] Summers. Robert, "Professor H.L.A. Hart Concept of Law," Duke Law Journal. Durham: Duke University School of Law, vol. 1963 (629), 1963.

[14] Syamsudin. M. (Ed), Ilmu Hukum Profetik: gagasan awal, Landasan Kefilsafatan dan Kemungkinan Pengembangannya di era Post modern. Yogyakarta: Pusat Studi Hukum UII, 2013.

[15] Brugt and Winkouman, SHidarta, Desertasi: 177. 2014

[16] Wardiono. Kelik, Paradigma Profetik: Pembaharuan Basis Epistimologi Ilmu Hukum. Yogyakarta: Genta, 2016. 